\title{
Nutritional and health functions of carbohydrate for pigs $^{*}$
}

\section{Y.-L. Yin ${ }^{1,2,4}$, Z.-Y. Deng ${ }^{1,2}$, H.-L. Huang ${ }^{2}$, H.Y. Zhong' ${ }^{2}$ Z.-P. Hou ${ }^{2}$, J. Gong ${ }^{3}$ and Q. Liu $^{3}$}

'Key Laboratory of Subtropical Agro-ecology, Institute of Subtropical Agriculture. The Chinese Academy of Sciences Changsha, Hunan, P.O. Box 10, Hunan 410125, P.R. China

'Department of Food Science and Engineering, Nanchang University Nanchang 330047, P.R.China

${ }^{3}$ Food Research Program, Agriculture and Agri-Food Canada, Guelph, ON, N1G5C, Canada

(Received 6 December 2003; revised version 31 May 2004; accepted 25 October 2004)

\begin{abstract}
The greatest progress in carbohydrate study in pig nutrition and health is that the carbohydrates are classified more clearly not only based on their structure, but also on their nutritional functions. Carbohydrates serve as components of cell structures, energy substrate and have regulatory functions. There are large differences in the digestion, absorption and the speed of the carbohydrates appearance in the portal vein blood plasma. Non-starch polysaccharides (NSP) and particularly soluble one and resistant starch (RS) may have negative effects on dietary nutrient utilization in pig growth, however, some of the NSP and RS have health benefits.
\end{abstract}

KEY WORDS: carbohydrate, pig, nutrition, health

\section{THE SIGNIFICANCE OF CARBOHYDRATE}

Carbohydrates are important in the nutrition of pigs because they are the primary source of energy that provides at least $50 \%$ of the total cost of

\footnotetext{
- Supported by National Basic Research Program of China (2004CB117502), (NSFC 30371038),

K.C. Wong Education Foundation Hong Kong and CAS (KSCX2-SW-232)

${ }^{4}$ Corresponding author: Yu-Long Yin, Institute of Subtropical Agriculture, the Chinese Academy of Sciences, Changsha, Hunan 410125, P.O. Box 10, P.R. China e-mail: yyulong2003@yahoo.com.cn
} 
pork production and because they affect digestion and the function of the gastrointestinal tract of pigs and humans. Since carbohydrates represent such a major part of the diet, characterizing their functions and improving their utilization are very important.

For growing pigs, up to about $50 \mathrm{~kg}$ body weight, feed intake capacity limits the expression of growth potency. Gut capacity of the pig from 20 to 50 $\mathrm{kg}$ liveweight is 1.8 to $2.0 \mathrm{~kg} / \mathrm{d}$, consequently it requires 12.1 to $14.4 \mathrm{MJ} / \mathrm{kg}$ metabolizable energy (ME) in the diet in order to achieve the optimum ME intake of 28.8 to $30.7 \mathrm{MJ} / \mathrm{d}$ for fast growing pigs (Campbell, 1990; Campbell et al., 1990). Furthermore, it has been suggested that fast growing pigs will experience rate of protein deposition (PDR) reduction of the order of $6 \mathrm{~g}$ for every $1 \mathrm{MJ}$ reduction in DE intake below the optimum (Rao and McCracken, 1991). This indicates that pig growth especially for the starter requires high digestible carbohydrate supply.

It has been found that many natural oligosaccharides can affect biological functions of animal (Spring and Privulescu,1998; Patterson and Burkholder, 2003). These developments let us re-recognize the importance of carbohydrates in life sciences. Moreover, as the advances of the studies of separation and structure analyses of carbohydrates, a new discipline has been emerged as "glycobiology" in recent years (Zhou, 1999). A "European Carbohydrate Platform" was initiated during 1994-1998 Research Program of European Commission. A "Glycobiology and Oligosaccharides Engineering Center" was created in the Chinese Academy of Sciences in 2001.

Oligosaccharides are produced in commercial quantities either by extraction from plant and bacterial sources, or more commonly by synthesis under the control of transglycosidase. The activity of these compounds as we understand them today is twofold: adsorption of enteric pathogens and immunomodulation (Spring and Privulescu, 1998). Oligosaccharides have widely used as additives in human, animal and plant. The world total oligosaccharide production was up to 130 thousand tones in 1998. Resistant starch (RS) and non-starch polysaccharides (NSP) can be also exploited for the development of functional foods for humans. Resistant starch and NSP can decrease dietary caloric value, which is important in the prevention of obesity. In addition RS and NSP can also reduce the risk of colonic cancer through increasing short-chain fatty acid production, especially butyrate.

\section{CLASSIFICATION OF CARBOHYDRATES}

Carbohydrates may be classified according to degree of polymerization; identity of constituent sugars and type of glycosidic linkages present. Table 1 shows this method of classification for food carbohydrates (Englyst and Hudson, 1996), as well as their likely fate in the small intestine. 
Classification of food carbohydrates (Englyst and Hudson, 1996)

\begin{tabular}{|c|c|c|c|c|}
\hline \multirow{3}{*}{ Type } & \multirow{3}{*}{$\begin{array}{l}\text { Constituent } \\
\text { sugar. }\end{array}$} & \multirow{3}{*}{$\begin{array}{l}\text { Hydrolysed } \\
\text { and absorbed } \\
\text { in the small } \\
\text { intestine }\end{array}$} & \multicolumn{2}{|c|}{$\begin{array}{l}\text { Included in analysed } \\
\text { NSP fraction }\end{array}$} \\
\hline & & & Englyst & $\mathrm{AOAC}$ \\
\hline & & & NSP & residue \\
\hline Sugars & glucose, fructose, sucrose, lactose & Mostly & No & No \\
\hline Sugar alcohols & sorbitol, xylitol, lactiol, maltitol & Sparsely & No & No \\
\hline $\begin{array}{l}\text { Short-chain } \\
\text { carbohydrates (SC) }\end{array}$ & $\begin{array}{l}\text { resistant SC (fructo-and galacto- } \\
\text { oligosaccharides, pyrodextrins, }\end{array}$ & No & No & No \\
\hline (soluble in 80 ethanol) & polydextrose), maltodextrins & Yes & No & No \\
\hline $\begin{array}{l}\text { Oligosaccharides } \\
<10 \text { monomers }\end{array}$ & $\begin{array}{l}\alpha \text {-galactosides (raffinose, } \\
\text { stachyose and verbascose) }\end{array}$ & No & No & No \\
\hline \multirow[t]{3}{*}{ Starch } & rapidly digestible starch & Yes & No & No \\
\hline & slowly digestible starch & Yes & No & No \\
\hline & resistant starch & No & No & Partly \\
\hline \multirow{2}{*}{$\begin{array}{l}\text { Non-starch } \\
\text { polysaccharides }\end{array}$} & present as plant cell-walls (dietary & No & Yes & Yes \\
\hline & mucilages, any isolated NSP) & No & Yes & Yes \\
\hline
\end{tabular}

The sugars are mostly absorbed in the small intestine. The major source of sugar alcohols in the diet is as additives and they are not well absorbed, and some that are absorbed are excreted in urine.

Short-chain carbohydrates are a new category in the classification of food carbohydrates. The current system of separating non-monomer carbohydrates into oligosaccharides and polysaccharides with a dividing point at about 10 monomer residues. In practice, the polysaccharides have been traditionally identified as the carbohydrate insoluble in $80 \%$ ethanol. Starch, a mixture of the $\alpha$-glucan polysaccharides amylose and amylopectin in proportions that depend on the botanical origin, represents $80-90 \%$ of all polysaccharides in the pig and human diets. These plant storage polysaccharides contain only $\alpha$-glucosidic linkages and are, therefore, potentially digestible by the amylolytic enzymes secreted by pig and human digestive tract. However, certain factors can influence the rate at which starch is hydrolysed and absorbed. It is therefore convenient to consider subdividing this class for nutritional purposes. Table 2

TABLE 2

In vitro nutritional classification of starch (Englyst et al., 1992)

\begin{tabular}{llc}
\hline Type of starch & Example of occurrence & $\begin{array}{c}\text { Probable digestion in small } \\
\text { intestine }\end{array}$ \\
\hline Rapidly digestible starch & Freshly cooked starch food & Rapid \\
\hline Slowly digestible starch & Most raw cereals & Slow but complete \\
$\begin{array}{l}\text { Resistant starch } \\
\text { physically inaccessible starch } \\
\text { resistant starch granules } \\
\text { retrograded starch }\end{array}$ & $\begin{array}{l}\text { Partly milled grains and seeds } \\
\text { Raw potato and banana } \\
\text { Cooled cooked potato, bread } \\
\text { and corn flakes }\end{array}$ & $\begin{array}{c}\text { Resistant } \\
\text { Resistant } \\
\text { Resistant }\end{array}$ \\
\hline
\end{tabular}


lists rapidly digestible starch, slowly digestible starch and resistant starch fractions. The rate and extent of the digestion of starch is reflected in the magnitude and the duration of the glycaemic response.

In vitro study shows that starch digestion is more slowly than simple sugar or disaccharides and its physical form is the major effect of digestion and absorption. The various types of starch are determined by controlled enzymatic hydrolysis and measurement of the released glucose using glucose oxidase according to the in vitro method of Englyst et al. (1992). Total starch is determined as the glucose released by enzymatic hydrolysis following gelatinization in boiling water and treatment with potassium hydroxide to disperse retrograded almost. Total starch is corrected for free glucose but includes maltose and maltodextrins. Rapidly digestible starch and slowly digestible starch are measured after incubation with pancreatic amylase and amyloglucosidase at $37^{\circ} \mathrm{C}$ for $20 \mathrm{~min}$ and a further $100 \mathrm{~min}$. Resistant starch is the starch not hydrolysed after $120 \mathrm{~min}$ incubation. Starch digestion index is calculated as: Starch digestion index $=$ rapidly digestible starch/total starch $\times 100$.

Rapidly available glucose (RAG): during the measurement of rapidly digestible starch and slowly digestible starch, a value is obtained for RAG as the glucose measured after $20 \mathrm{~min}$ incubation with the enzymes. Rapidly available glucose $=$ free glucose + glucose from sucrose + glucose released from starch with 20 min incubation. Various types of starch and its ileal digestibility in some carbohydrate ingredients are listed in Tables 3 and 4.

The NSP comprise $700-900 \mathrm{~g} / \mathrm{kg}$ of the plant cell wall, with the remaining being lignin, protein, fatty acids, waxes, etc. (Bach Knudsen, 2001). Plant cell wall NSP is a diverse group of molecules with varying degrees of water solubility, size and structure, which may influence the rheological properties of the gastrointestinal

TABLE 3

In vifro digestibility (g/100 $\mathrm{g}$ DM) of some carbohydrate-containing ingredients (Englyst et al., 1992)

\begin{tabular}{lcccccc}
\hline Sample & $\begin{array}{c}\text { Rapidly } \\
\text { digestible } \\
\text { starch }\end{array}$ & $\begin{array}{c}\text { Slowly } \\
\text { digestible } \\
\text { starch }\end{array}$ & $\begin{array}{c}\text { Resistant } \\
\text { starch }\end{array}$ & $\begin{array}{c}\text { Total } \\
\text { starch }\end{array}$ & $\begin{array}{c}\text { Starch } \\
\text { digestion } \\
\text { index }\end{array}$ & $\begin{array}{c}\text { Rapidly } \\
\text { available } \\
\text { glucose }\end{array}$ \\
\hline Wheat flour & 40 & 39 & 2 & 81 & 49 & 40 \\
Maize & 73 & 2 & 3 & 78 & 94 & 81 \\
Oats & 57 & 6 & 2 & 65 & 88 & 49 \\
White rice & 60 & 12 & 6 & 78 & 93 & 81 \\
Cooked rice & 78 & 1 & $<1$ & 79 & 98 & 86 \\
Potato starch (raw) & 6 & 19 & 75 & 99 & 6 & 5 \\
Banana flour & 3 & 15 & 57 & 75 & 4 & 6 \\
Faba bean & 27 & 16 & 6 & 49 & 55 & 8 \\
Peas & 12 & 2 & 5 & 20 & 60 & 9 \\
Glucose & 100 & & & 100 & 100 & 100 \\
\hline
\end{tabular}


TABLE 4

Total and resistant starch (RS) composition (\%) and ileal digestibility (\%) of starch of sorghum (SG), pear millet (PM), high oil maize (HOM), high oil high protein maize (HOPM), normal maize $\mathrm{I}(\mathrm{CI})$ and normal maize II fed to growing pigs (CII) (Yin et al., 2002)

\begin{tabular}{lccccc}
\hline \multirow{2}{*}{ Ingredients } & $\begin{array}{c}\text { Total starch } \\
\%\end{array}$ & \multicolumn{3}{c}{ Resistant starch } & Digestibility \\
\cline { 3 - 5 } & $\%$ & $0.5 \mathrm{~h}$ & $3 \mathrm{~h}$ & $16 \mathrm{~h}$ & $\%$ \\
\hline Sorghum & 58 & 34 & 8 & 0.2 & 96.5 \\
Millet & 52 & 32 & 3 & 0.2 & 97.8 \\
HOM & 50 & 31 & 4 & 0.1 & 98.6 \\
HOPM & 44 & 23 & 2 & 1.3 & 98.4 \\
CI & 66 & 39 & 6 & 1.7 & 98.1 \\
CII & 62 & 39 & 7 & 0.1 & 98.5 \\
\hline
\end{tabular}

contents, flow of digesta and the digestion and absorption process to a variable degree. The action of NSP in the stomach and small intestine is essentially a physical one, in which the plant cell either acts as barrier to the release of nutrients or increases the viscosity of the liquid phase and restricts their absorption. The effect of NSP on the digestion and absorption in the small intestine is more difficult to predict from any of the chemical parameters currently measured.

Over 100 monosacharides are found in nature but only about nine of these are the predominant building blocks of NSP (Albersheim et al., 1984; Henry, 1985). These include the pentoses (arabinose and xylose), the hexoses (glucose, mannose and galactose), the 6-deoxyhexoses (rhamnose and fucose) and the hexauronic acids (galacturonic acid, glucuronic acid). These sugars are joined by glycosidic bonds between the hemiacetal group of one sugar and the hydroxyl group of another. The bonds are identified by the carbon atoms of each sugar that are involved in the bond ( 1 to 6 for hexoses and 1 to 5 for pentoses) and the orientation of the oxygen atom in the hemiacetal group (primarily $\beta$ ). The number of potential polysaccharide structures is enormous (Albersheim et al., 1984).

The main NSP composition in cereal grain are list in Table 5. The results show that arabinose and xylose are the major NSP compounds in wheat and rice seed endosperm, while content of glucan in barley is higher than that in wheat and rice seed.

Most ingested vegetable materials have a high water-holding capacity with most water retained within the lumen in the pig, begins to macerate the tissue reducing the mean particle size until, when reaching the hindgut, some $90 \%$ of dry matter has been fermented and virtually all structure and thus waterholding and bulking capacity has disappeared. Lignified cell walls, in contrast, although losing some $40 \%$ of dry matter due to microbial action, tend to retain their cellular integrity and their bulking capacity throughout the digestive tract as shown in Table 6 . This difference in the extent to which physical structure is retained in reflected in significant effects on gut motility and transit time. 
TABLE 5

Detailed sugar composition of non-starch polysaccharides (\%) for a range of cereal grain

\begin{tabular}{|c|c|c|c|c|c|c|c|c|c|c|}
\hline \multicolumn{2}{|l|}{ Sample } & $\begin{array}{l}\text { Total } \\
\text { NSP }\end{array}$ & $\begin{array}{l}\text { Rham- } \\
\text { nose }\end{array}$ & $\begin{array}{l}\text { Fuc- } \\
\text { tose }\end{array}$ & $\begin{array}{l}\text { Arabi- } \\
\text { nose }\end{array}$ & Xylose & $\begin{array}{l}\text { Man- } \\
\text { nose }\end{array}$ & $\begin{array}{l}\text { Galac- } \\
\text { tose }\end{array}$ & $\begin{array}{l}\text { Glu- } \\
\text { cose }\end{array}$ & $\begin{array}{l}\text { Uronic } \\
\text { acids }\end{array}$ \\
\hline \multirow{3}{*}{ Wheat $^{1}$} & $\mathrm{Sol}^{1}$ & 1.4 & 0.03 & 0.02 & 0.33 & 0.17 & 0.03 & 0.35 & 0.17 & 0.25 \\
\hline & $\operatorname{Ins}^{2}$ & 12.6 & 0.04 & 0.04 & 3.62 & 5.25 & 0.17 & 0.38 & 2.56 & 0.55 \\
\hline & Total & 14.0 & & & & & & & & \\
\hline \multirow{3}{*}{ Barley $^{1}$} & Sol & 1.4 & 0.019 & 0.02 & 0.24 & 0.12 & 0.029 & 0.22 & 0.59 & 0.18 \\
\hline & Ins & 12.3 & 0.03 & 0.03 & 2.96 & 4.8 & 0.21 & 0.27 & 3.68 & 0.35 \\
\hline & Total & 13.7 & & & & & & & & \\
\hline \multirow{3}{*}{$\begin{array}{l}\text { Wheat } \\
\text { bran }^{1}\end{array}$} & Sol & 3.2 & 0.076 & 0.068 & 0.64 & 0.47 & 0.1 & 0.74 & 0.6 & 0.5 \\
\hline & Ins & 68.9 & 0.18 & 0.98 & 17.3 & 32.2 & 0.51 & 1.42 & 14.3 & 2.01 \\
\hline & Total & 72.1 & & & & & & & & \\
\hline \multirow{3}{*}{$\begin{array}{l}\text { Rice } \\
\text { bran }^{3}\end{array}$} & Sol & 3.0 & 0.07 & 0.05 & 0.52 & 0.41 & 0.1 & 0.64 & 0.50 & 0.41 \\
\hline & Ins & 74.1 & 0.20 & 1.0 & 19.5 & 35.2 & 0.61 & 1.00 & 14.6 & 2.03 \\
\hline & Total & 77.1 & & & & & & & & \\
\hline \multirow{3}{*}{$\begin{array}{l}\text { Oats- } \\
\text { hulled }\end{array}$} & Sol & 4.0 & & & & & & & & \\
\hline & Ins & 11.0 & & & & & & & & \\
\hline & Total & 15.0 & & & & & & & & \\
\hline \multirow{3}{*}{$\begin{array}{l}\text { Oats- } \\
\text { hulless }\end{array}$} & Sol & 5.4 & & & & & & & & \\
\hline & Ins & 4.9 & & & & & & & & \\
\hline & Total & 10.3 & & & & & & & & \\
\hline \multirow{3}{*}{$\begin{array}{c}\text { Oat hull } \\
\text { meal }^{4}\end{array}$} & Sol & 1.3 & & & & & & & & \\
\hline & Ins & 29.5 & & & & & & & & \\
\hline & & & & & & & & & & \\
\hline \multirow{3}{*}{$\begin{array}{c}\text { Sugar } \\
\text { beet } \\
\text { pulp }\end{array}$} & & 40.7 & & & & & & & & \\
\hline & Ins & 17.7 & & & & & & & & \\
\hline & Total & 58.4 & & & & & & & & \\
\hline
\end{tabular}

${ }^{1}$ soluble

${ }^{2}$ insoluble

${ }^{3}$ Yin et al., 2000a,b,c; 2001a,b

${ }^{4}$ Bach Knudsen, 2001

\section{CARBOHYDRATE DIGESTION AND ABSORPTION}

Non-starch polysaccharides (NSP) or acid detergent fibre (ADF) and neutral detergent fibre (NDF) digestibility at the terminal ileum

The ileal digestibility of NSP, ADF and NDF varied between experiments. The ileal digestibility of NSP, ADF and NDF at this site of the gastrointestinal 
TABLE 6

Comparison of the effects of fibre from a readily fermentable vegetable source (Rutabaga) and a less fermentable cereal source (wheat bran) on the digestive physiology of a growing $(70 \mathrm{~kg}) \mathrm{pig}$ (Chesson, 1998)

\begin{tabular}{lcc}
\hline Parameter & Wheat bran & Rutabaga \\
\hline Total fibre in diet, g/kg DM & 250 & 250 \\
Soluble fibre, g/kg DM & 22.9 & 71.2 \\
Lignin, g/kg DM & 19.8 & 2.9 \\
Water-holding capacity, g $\mathrm{H}_{2} \mathrm{O} / \mathrm{g} \mathrm{DM}$ & 2.9 & 32.1 \\
Overall digestibility, \% & 41.5 & 87.8 \\
Ileal digestibility, \% & 4.6 & 45.2 \\
Particle size in diet, $\mu \mathrm{m}$ & 1197 & 2398 \\
Particle size in faeces, $\mu \mathrm{m}$ & 907 & 228 \\
Transit time, h & 36 & 58 \\
Total VFA-terminal ileum, $\mathrm{mmol}_{\mathrm{kg} \text { DM }}$ & 124 & 191 \\
Total VFA-caecum, mmol/kg DM & 1180 & 3035 \\
Total anaerobes-terminal ileum, $\log _{10} \mathrm{cfu} / \mathrm{g} \mathrm{DM}$ & 10.5 & 8.2 \\
Total anaerobes-caecum, $\log _{10} \mathrm{cfu} / \mathrm{g} \mathrm{DM}$ & 10.4 & 11.2 \\
\hline
\end{tabular}

tract is influenced by the type of dietary fibre, but factors of feeding levels and sampling techniques, etc. are probably also involved in. The ileal digestibility of NSP, ADF and NDF in some cereal and legume diets are presented in Table 7.

TABLE 7

Ileal digestibility (\%) of non-starch polysaccharides (NSP), acid detergent fibre (ADF) and neutral detergent fibre (NDF) in some feedstuff fed to growing pigs (Yin et al., 1993, 1994, 2000, 2001; Bach Knudsen, 2001)

\begin{tabular}{lccc}
\hline Diet & NSP & ADF & NDF \\
\hline Rice seed & & 23 & 38 \\
Peanut meal & & 32 & 41 \\
Rapeseed meal & & 37 & 46 \\
Cottonseed meal & & 40 & 44 \\
Soyabean & & 38 & 46 \\
Peas & 15 & 31 & 52 \\
Wheat bran & & 38 & 58 \\
Maize & & 39 & 62 \\
Jack bean & 25 & 64 \\
Mung bean & 15 & \\
Hulless barley & 20 & & \\
Wheat middling & 30 & & \\
Oat bran & 36 & & \\
Sugar beet pulp & 37 & & \\
Peas & 40 & & \\
\hline
\end{tabular}

\section{Sugar and starch absorption}

As the supply of energy-yielding nutrients at the sites of protein synthesis should be synchronized with the supply of amino acids to make the synthetic process optimal, variation in the nutritive value of sugars might be due to a 
different chronology in the digestion and absorption of their hydrolysis products, as well as to the different nature of the later. Until now, most of the estimation of the amounts of nutrient available for the pig during digestion was made by the means of the digestibility studies, but only few studies were conducted to quantify the precise kinetics of their appearance in the organism and their transformation during transit and absorption. Rerat et al. (1984) and Yen et al. (1987) have developed the method for chronically quantifying net absorption of nutrients and gut metabolites into hepatic portal vein in conscious pigs, however, the surgery technique is complex and time-consuming. Recently, we have made some development on the techniques for cannulating the portal vein blood vessels described by Rerat et al. (1980) and Yen et al. (1987) and made the technique easy to use (Huang et al., 2003).

Rerat et al. (1984), studied the digestion and absorption of four different types of carbohydrates (glucose, sucrose, lactose and maize starch) in conscious pigs with a technique based on the determination of blood flow-rate in the portal vein combined with the measurement of the portal-arterial differences of nutrients. They suggested: 1. the supply of energy is not chronologically the same when another replaces one sugar even for an unchanged dietary energy content (Table 8), 2. what influence, however, do such variations have on the utilization of carbohydrates and proteins by the tissues?, 3. the slow digestion of some carbohydrates, such as lactose, may favour the arrival of fermentable substrates in the large intestine leading to formation of either useful or noxious substances. We have also studied the net glucose absorption in portal vein when pigs were fed two different carbohydrate diets: a maize starch based diet and the starch based diet being replaced by $8 \%$ of pectin (soluble NSP). The results are shown in Table 8.

TABLE 8 Amounts ( $\mathrm{g}$ ) of glucose appearing in the portal blood during a post-prandial period of $8 \mathrm{~h}$ after intake of different carbohydrates (Rerat et al., 1984 and Yin et al., 2002, unpublished')

\begin{tabular}{|c|c|c|c|c|c|}
\hline \multirow{2}{*}{$\begin{array}{l}\text { Carbohydrates } \\
\text { intake, } \mathrm{g}\end{array}$} & \multirow[t]{2}{*}{ Carbohydrate } & \multicolumn{4}{|c|}{$\begin{array}{l}\text { Cumulative amount of glucose appearing in the } \\
\text { portal vein, } g\end{array}$} \\
\hline & & $2 \mathrm{~h}$ & $4 \mathrm{~h}$ & $6 \mathrm{~h}$ & $8 \mathrm{~h}$ \\
\hline 400 & Glucose & 65.2 & 156.3 & 195.4 & 207.5 \\
\hline 400 & Sucrose & 48.4 & 96.2 & 123.6 & 137.0 \\
\hline 400 & Lactose & 25.7 & 50.5 & 67.2 & 77.4 \\
\hline 400 & Maize starch & 61.7 & 110.7 & 148.0 & 183.2 \\
\hline 800 & Glucose & 133.2 & 304.6 & 413.9 & 509.7 \\
\hline 800 & Sucrose & 69.2 & 162.1 & 237.1 & 283.5 \\
\hline 800 & Lactose & 20.5 & 39.6 & 57.4 & 73.5 \\
\hline 800 & Maize starch & 88.7 & 185.9 & 254.0 & 309.0 \\
\hline $337^{\prime}$ & Maize starch & 52.5 & 91.3 & 123.9 & $131.2(7 \mathrm{~h})$ \\
\hline $293^{\prime}$ & Maize starch $+8 \%$ pectin & 39.9 & 67.2 & 93.7 & $99.0(7 \mathrm{~h})$ \\
\hline
\end{tabular}


EFFECTS OF NON-STARCH POLYSACCHARIDES (NSP) ON PIG NUTRIENT UTILIZATION AND GASTROINTESTINAL BACTERIAL FERMENTATION

Non-starch polysaccharides (NSP) and particularly soluble ones, which have antinutritional properties by changing the function of the gastrointestinal tract. Soluble NSP encapsulate nutrients and thus depress overall nutrient digestibility and increase endogenous nitrogen flow and bacterial fermentation in the gastrointestinal tract. Yin et al. (2000a) reported that NSP stimulate endogenous $\mathrm{N}$ flow (Table 9) and hindgut fermentation (Table 10). The results of Table 10

TABLE 9

Effect of wheat non-starch polysaccharides (NSP) on dry matter (DM) and nitrogen (N) flows at the terminal ileum (Yin et al., 2000a)

\begin{tabular}{lcccc}
\hline Indices & Wheat & $\begin{array}{c}\text { Wheat } \\
\text { middling }\end{array}$ & $\begin{array}{c}\text { Wheat } \\
\text { bran }\end{array}$ & SEM \\
\hline Dictary NSP level, g/kg DM & 87 & 150 & 190 & \\
DM/g/kg DM intake & $236.9^{\mathrm{c}}$ & $375.9^{\mathrm{b}}$ & $413.1^{\mathrm{a}}$ & 10.42 \\
Total N, g/kg DM intake & $6.7^{\mathrm{b}}$ & $9.47^{\mathrm{a}}$ & $9.37^{\mathrm{a}}$ & 0.444 \\
Endogenous N, g/kg DM intake & $4.14^{\mathrm{b}}$ & $6.42^{\mathrm{a}}$ & $5.98^{\mathrm{a}}$ & 0.527 \\
\hline
\end{tabular}

a.b.c values in the same row with different superscript letters differ at $\mathbf{P}<0.05$

TABLE 10

Effects of dictary non-starch polysaccharides (NSP) level and enzyme cocktail supplementation on apparent ileal and overall digestibility and hindgut fermentation (HF) (\%) of dry matter, gross energy, crude protein, neutral detergent fibre (NDF) and NSP of pigs fed Phoenix, Falcon, Silky, Buck and Condor based diets ' (Yin et al., 200 lb)

\begin{tabular}{|c|c|c|c|c|c|c|c|}
\hline & \multicolumn{5}{|c|}{ Diet } & \multicolumn{2}{|c|}{ Enzyme } \\
\hline & Phoenix & Falcon & Silky & Condor & Back & - & + \\
\hline Dietary NSP level, g/kg DM & 138.2 & 140.0 & 145.8 & 153.9 & 154.8 & & \\
\hline \multicolumn{8}{|l|}{ Ileal digestibility } \\
\hline dry matter & $63.4^{\text {* }}$ & $61.4^{\mathrm{ab}}$ & $60.0^{\mathrm{hc}}$ & $60.6^{\mathrm{be}}$ & $58.3^{\mathrm{c}}$ & $58.4^{\mathrm{b}}$ & $63.1^{\mathrm{a}}$ \\
\hline gross energy & $64.3^{\mathrm{a}}$ & $62.3^{\mathrm{ab}}$ & $60.6^{\mathrm{hi}}$ & $61.9^{\mathrm{he}}$ & $59.0^{\mathrm{c}}$ & $59.0^{\mathrm{h}}$ & $64.4^{4}$ \\
\hline crude protein & $70.6^{a}$ & $67.4^{\mathrm{ab}}$ & $66.1^{\mathrm{h}}$ & $57.1^{\mathrm{c}}$ & $57.3^{\mathrm{c}}$ & $62.1^{b}$ & $66.4^{*}$ \\
\hline NDF & 17.2 & 17.5 & 17.5 & 18.8 & 15.9 & $13.0^{b}$ & $20.0^{\mathrm{a}}$ \\
\hline NSP & 29.3 & 30.1 & 31.6 & 27.8 & 31.7 & $25.5^{\mathrm{b}}$ & $33.6^{\mathrm{a}}$ \\
\hline \multicolumn{8}{|l|}{ Overall digestibility } \\
\hline gross energy & $79.9^{\mathrm{a}}$ & $76.0^{\mathrm{b}}$ & $75.4^{\mathrm{b}}$ & $76.6^{\mathrm{b}}$ & $76.5^{b}$ & $75.3^{b}$ & $78.9^{\mathrm{a}}$ \\
\hline crude protein & $74.7^{\mathrm{a}}$ & $71.8^{\mathrm{b}}$ & $71.2^{\mathrm{b}}$ & $72.4^{\mathrm{b}}$ & $72.3^{b}$ & 71.4 & 73.4 \\
\hline NDF & 51.6 & 52.0 & 56.4 & 54.8 & 52.2 & $50.4^{\mathrm{b}}$ & $56.5^{\mathrm{a}}$ \\
\hline \multicolumn{8}{|l|}{ HF digestibility } \\
\hline dry matter & 47.0 & 45.1 & 41.5 & 41.1 & 40.3 & $45.0^{\mathrm{a}}$ & $41.6^{\mathrm{b}}$ \\
\hline gross energy & 43.7 & 39.8 & 37.6 & 40.1 & 38.3 & $41.2^{a}$ & $37.3^{\mathrm{h}}$ \\
\hline crude protein & $13.9^{\mathrm{h}}$ & $13.5^{b}$ & $15.0^{\mathrm{b}}$ & $20.2^{\mathrm{a}}$ & $23.0^{\circ}$ & $9.9^{\mathrm{a}}$ & $7.3^{\mathrm{h}}$ \\
\hline NDF & 41.5 & 40.0 & 37.8 & 38.9 & 43.2 & $40.0^{\mathrm{a}}$ & $31.1^{\mathrm{th}}$ \\
\hline
\end{tabular}

$\mathrm{i}$ fermentation expressed as a proportion of undigested material reaching hindgut (=fermentation expressed as the difference between overall and ileal digestibility/100 - ileal digestibility)

a.b.c values in the same row with different superscript letters differ $(\mathrm{P}<0.05)$ 
show that more than $70 \%$ of dietary gross energy and $85 \%$ of crude protein in the test barley is digested in the small intestine. A significantly higher hindgut fermentation of crude protein for the higher NSP diets of condor and buck than others indicated that the extent of microflora digestion of dietary protein in the hindgut depends on the amount of fermentable carbohydrate and protein reaching the large intestine. Since the ileal digestibility of dry matter, energy and protein in the diets of condor and buck were significantly lower than others; these two varieties of barley may provide a high amount of fermentable carbohydrate and protein in the large intestine, which potentially could enhance the growth of microflora. However, fermentation of undigested dietary protein residues by microflora in the large intestine yield products of no nutritional value to the pig (Żebrowska, 1973) and the net energy value utilized from the small intestine is $30 \%$ higher than that from the large intestine (Dierick et al., 1989). Bach Knudsen (2001) summarized the effects of soluble, insoluble and total dietary fibre on rheological properties of the gastrointestinal content and digestion and absorption processes in pigs (Table 11). Undigested soluble NSP may exacerbate such diseases as dysentery. Hence, controlling hindgut microbial activity, particularly through nutritional means, may be of increasing relevance as the use of feed antibiotics is more and more constrained.

TABLE 11

Summary of effects of soluble, insoluble and total dietary fibre on rheological properties of the gastrointestinal content and digestion and absorption processes in pigs (Bach Knudsen, 2001)'

\begin{tabular}{|c|c|c|c|}
\hline \multirow{2}{*}{ Indices } & \multicolumn{3}{|c|}{ Dictary fibre } \\
\hline & soluble & insoluble & total \\
\hline \multicolumn{4}{|l|}{ Stomach } \\
\hline viscosity & $* * *$ & * & ** \\
\hline $\mathrm{WBC}^{2}$ & $* *$ & $* * *$ & $* *$ \\
\hline emptying & $*(*)$ & $*$ & * \\
\hline \multicolumn{4}{|l|}{ Small intestine } \\
\hline viscosity & ** & - & $*$ \\
\hline WBC & $* *$ & $* * *$ & $* * *$ \\
\hline glucose absorption & $(*)$ & - & - \\
\hline \multicolumn{4}{|l|}{ Large intestine } \\
\hline fermentation & $* * * *$ & $* * *$ & $* * *$ \\
\hline bulking & * & $* * * *$ & $* * * *$ \\
\hline $\mathrm{MTT}^{3}$ & - & $* * *$ & $* * *$ \\
\hline \multicolumn{4}{|l|}{ Energy } \\
\hline ileum & $* * *$ & $* * * *$ & $* * * *$ \\
\hline faeces & - & $* * * *$ & $* * * *$ \\
\hline
\end{tabular}


Some disease conditions, such as swine dysentery and acidosis in ruminants and horses, have great economic significance and are closely related to the status of the gut microfloral fermentation. For an example, pig dysentery is caused by a spirochaete bacterium that resides in the large intestine, and the proliferation of this bacterium is inhibited by low rates of fermentation, as indicated by Pluske et al. $(1996,1998)$. They showed that diets based on cooked rice and animal proteins can give a high level of protection against pig dysentery. Steam-flaking of maize and sorghum can also eliminate or largely reduce the incidence of pig dysentery, but this type of processing is ineffective for wheat, barley, or groats. The increased fermentation in the large intestine may be due to an elevated level of NSP in the diet. In the case of maize and sorghum, steam-flaking may have disrupted the cell wall matrix, making the starch granules more susceptible to amylase, thereby speeding up starch digestion in the upper part of the gut (Figure 1, Table 12).

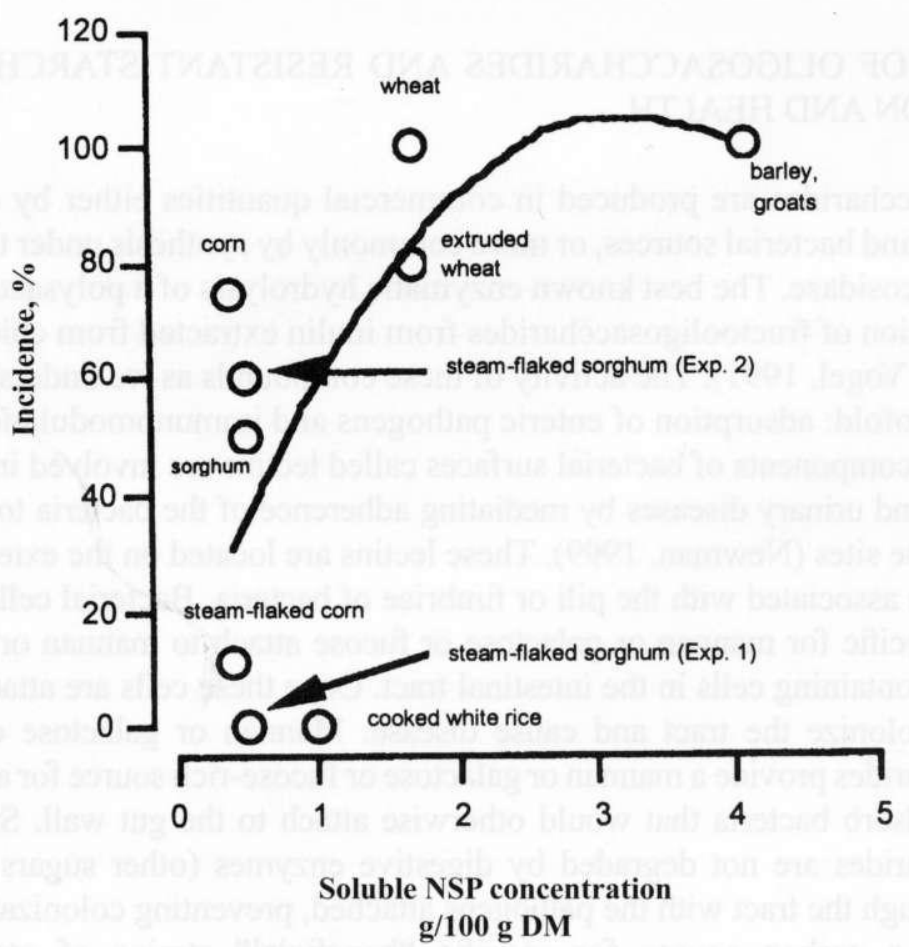

Figure 1. The relationship between the incidence of pig dysentery (\%) and soluble non-starch polysaccharides (NSP) concentration of diets $(\mathrm{g} / 100 \mathrm{~g} \mathrm{DM})\left(\mathrm{y}=9.52+56.98 \mathrm{x}-8.47 \mathrm{x}^{2} ; \mathrm{R}^{2}=0.561\right)$ (Pluske et al., 1996) 
TABLE 12

Development of pig dysentery in animals infected with Serpulina hydosenteriae and fed rice-based diets containing different sources of carbohydrate or an animal protein-soyabean meal supplement or increasing levels of resistant starch (RS) (Pluske, 1998)

\begin{tabular}{|c|c|c|c|c|c|c|c|c|}
\hline & \multicolumn{8}{|c|}{ Diet } \\
\hline & \multirow{2}{*}{$\begin{array}{l}\text { rice- } \\
\text { guar } \\
\text { gum }\end{array}$} & \multirow{2}{*}{$\begin{array}{l}\text { rice- } \\
\text { RS }\end{array}$} & \multirow{2}{*}{$\begin{array}{l}\text { rice-oat } \\
\text { chaff }\end{array}$} & \multirow{2}{*}{$\begin{array}{c}\text { rice- } \\
\text { guar } \\
\text { gun+RS }\end{array}$} & \multirow{2}{*}{$\begin{array}{l}\text { rice- } \\
\text { animal } \\
\text { protein }\end{array}$} & \multicolumn{3}{|c|}{ rice-RS } \\
\hline & & & & & & $13.2 \%$ & $20 \%$ & $27 \%$ \\
\hline $\begin{array}{l}\text { S. hydosenteriae } \\
\text { isolated from } \\
\text { rectal swabs }\end{array}$ & 5 & 5 & 1 & 5 & 0 & 5 & 5 & 5 \\
\hline Incidence of SD & 4 & 0 & 0 & 5 & 0 & 5 & 4 & 3 \\
\hline Faecal shedding & 19 & 11 & 1 & 17 & 0 & 12 & 14 & 16 \\
\hline $\begin{array}{l}\text { Post-morten } \\
\text { gross lesions }\end{array}$ & 4 & 0 & 0 & 5 & 0 & 5 & 4 & 4 \\
\hline $\begin{array}{l}S . \text { hydosenteriae } \\
\text { isolated from } \\
\text { lesions }\end{array}$ & 4 & 0 & 0 & 5 & 0 & 5 & 4 & 5 \\
\hline
\end{tabular}

\section{EFFECTS OF OLIGOSACCHARIDES AND RESISTANT STARCH ON PIG NUTRITION AND HEALTH}

Oligosaccharides are produced in commercial quantities either by extraction from plant and bacterial sources, or more commonly by synthesis under the control of transglycosidase. The best known enzymatic hydrolysis of a polysaccharides is the production of fructooligosaccharides from inulin extracted from chicory roots (Heinz and Vogel, 1991). The activity of these compounds as we understand them today is twofold: adsorption of enteric pathogens and immunomodulation.

Certain components of bacterial surfaces called lectins are involved in the onset of enteric and urinary diseases by mediating adherence of the bacteria to epithelial cells in these sites (Newman, 1999). These lectins are located on the exterior of the cell and are associated with the pili or fimbriae of bacteria. Bacterial cells with pili that are specific for mannan or galactose or fucose attach to mannan or galactose or fucose-containing cells in the intestinal tract. Once these cells are attached, they can then colonize the tract and cause disease. Mannan or galactose or fucoseoligosaccharides provide a mannan or galactose or fucose-rich source for attachment that will adsorb bacteria that would otherwise attach to the gut wall. Since these oligosaccharides are not degraded by digestive enzymes (other sugars do), they passes through the tract with the pathogens attached, preventing colonization.

Act as a carbon source for specific "beneficial" strains of gut bacteria encouraging their numbers to increase the proportion of the total flora (Chesson and Austin, 1998). 
Several studies have been conducted in examining the role of oligosaccharides on binding of pathogens to epithelial cells in GIT. Nemcova et al. (1999) determined the effect of feeding oligofructose and Lactobacillus paracasei on the microbiota of pigs weaned at 36 days of age. Feeding the symbiotic combination resulted in higher numbers of total anaerobes, total aerobes and Lactobacilli. They observed a decrease in enterobacteria and clostridia. Farnworth et al. (1992) fed weanling pigs with oligofructose and found there were numerical increases in total anaerobes, total aerobes, bifidobacteria and coliforms.

A number of trials have shown trends for improvements in growth performance, decrease in variation, mortality and morbidity associated with feeding prebiotics to pigs. Estrada et al. (2001) fed early weaned pigs oligofructose for 21 days with two inoculations of Bifidobacterium longum in the first week. There was a numerical increase in gain and a significant improvement of feed efficiency in pigs fed the symbiotic combination. Orban et al. (1997) observed numerical increases in performance of weaned pigs fed oligofructose or an antibiotic in 2 trials. Antibiotic response was numerically higher than oligofructose response in these studies.

Now many scientists consider resistant starch (RS) has the same functions as oligosaccharides. Pig caecal and colonic bacteria ferment RS to short-chain fatty acids (SCFA), maily acetate, propionate and butyrate. Short-chain fatty acids stimulate caecal and colonic blood flow and fluid and electrolyte uptake. Butyrate is a preferred substrate for colonocytes and appears to promote a normal phenotype in these cells (Topping and Clifton, 2001). Topping et al. (1993) reported that $\mathrm{pH}$ values are lower in pigs fed diets that raise large bowel SCFA. Lower $\mathrm{pH}$ values are believed to prevent the overgrowth of $\mathrm{pH}$-sensitive pathogenic bacteria (Cherrington et al., 1991). Kleessen et al. (1997) reported that RS stimulate large intestinal Lactobacilli production on rats, although the Enterobacteria were stimulated by retrograded starch (Table 13).

TABLE 13

Effects of $10 \%$ raw (RS 1) and 10\% retrograded potato starch (RS 2) in the diet on caecal bacterial counts after a 5-month experimental period (Kleessen et al., 1997)

\begin{tabular}{lrcccccc}
\hline Treatment & Total & $\begin{array}{c}\text { Fusobac- } \\
\text { teria }\end{array}$ & $\begin{array}{c}\text { Bifidobac- } \\
\text { teria }\end{array}$ & Clostridia & $\begin{array}{c}\text { Lactoba- } \\
\text { cilli }\end{array}$ & $\begin{array}{c}\text { Strepto- } \\
\text { cocci }\end{array}$ & $\begin{array}{c}\text { Enterobac- } \\
\text { teria }\end{array}$ \\
\hline Control & 10.0 & 9.8 & $6.6^{\mathrm{c}}$ & 6.8 & $8.9^{\mathrm{d}}$ & $6.6^{\mathrm{d}}$ & $5.4^{\mathrm{d}}$ \\
RS 1 & 9.9 & 9.2 & $9.0^{\mathrm{d}}$ & 6.9 & $8.7^{\mathrm{d}}$ & $7.0^{\mathrm{d}}$ & $5.3^{\mathrm{d}}$ \\
RS 2 & 10.5 & 9.7 & $8.9^{\mathrm{d}}$ & 6.5 & $10.3^{\mathrm{e}}$ & $9.3^{\mathrm{e}}$ & $8.2^{\mathrm{e}}$ \\
SEM & 0.2 & 0.3 & 0.3 & 0.5 & $0.2^{2}$ & $0.2^{2}$ & 0.4 \\
\hline
\end{tabular}

d.e values in the same column with different superscript letters differ $(\mathrm{P}<0.05)$ 


\section{CONCLUSIONS}

Carbohydrate is an important component in pig rations that not only provide the majority of energy for pigs, but also comprise some components which limit feed intake, digestibility and absorption, and affects pig performance. The importance of gluco- or glyconization in the life cell indicates that carbohydrate has important biological function. Due to complex structure of the carbohydrate, its effects on nutrients digestion, absorption and the gastrointestinal tract bacterial production are still not very clear and further investigation is needed. In the view of practice, it is very important to develop economic techniques for producing the rapidly digestible and resistant starch from maize and rice for providing a highly digestible carbohydrate ingredient for young pigs and prebiotics as an alternative to antibiotics.

\section{REFERENCES}

Albersheim P., Darvill A.G., Davis K.R., Lau J.M., McNeil M., Sharp J.K.,York W.S., 1984. Why study the structure of biological molecules? In: W.M. Dugger, S. Bartnicki-Garci (Editors). Structure, Function and Biosynthesis of Plant Cell Walls. American Society of Plant Physiologists, Rockville, MD, pp. 18-51

Bach Knudsen K.E., 2001. The nutritional significance of dietary fiber analysis. Anim. Feed Sci. Tech. 90, 3-20

Campbell R.G., 1990. The effects of protein deposition capacity on the growing pig requirements for dietary nutrients. Proceeding of Arkansas Nutrition Conference, pp. 117-124

Campbell R.G., Johnson R.J., King, R.H.,Taverner M.R., 1990. Effects of gender and genotype on the response of growing pig to exogenous administration of porcine growth hormone. J. Anim. Sci. $68,2674-2681$

Cherrington C.A., Hinton M., Pearson G.R., Chopra I., 1991. Short-chain organic acids at pH 5.0 kill Escherichia coli and Salmonella spp. without causing membrane perturbation. J. Appl. Bacteriol. 70, 161-165

Chesson A., Austin S., 1998. Defining the nutritional characteristics of plant carbohydrates - the non-ruminant perspective. In: Proceeding of the $19^{\text {th }}$ Western Nutrition Conference, Saskatoon (Canada), pp. 205-210

Dierick N., Vervaeke I.L., Demeyer D.I., Decuypere J., 1989. Approach to the energetic importance of fiber digestion in pigs. Anim. Feed Sci. Tech. 23, 141-168

Englyst H.N., Hudson G.J., 1996. The classification and measurement of dietary carbohydrates. Food Chem. 57, 15-21

Englyst H.N., Kingman S.M., Cummings J.H., 1992. Classification and measurement of nutritional important starch fractions. Eur. J. Clin. Nutr. 46, Suppl. 2, S33-S50

Estrada A., Drew A.D., van Kessel A., 2001. Effect of the dietary supplementation of fructooligosaccharides and Lactobacillus longum to early-weaned pigs on performance and faecal bacterial populations. Can. J. Anim. Sci. 81, 141-148

Farnworth E.R., Modler H.W., Jones J.D., Cave N., Yamazaki H., Rao A.V., 1992. Feeding Jerusalem artichoke flour rich in fructooligosaccharides to weanling pigs. Can. J. Anim. Sci. 72, 977-980

Heinz F., Vogel M., 1991. Process for preparing a low glucose, fructose and saccharose inulooligosaccharide product. European Patent 0440074 A1 
Henry R.J., 1985. A comparison of the non-starch carbohydrates in cereal grains. J. Sci. Food Agr. $36,1243-1253$

Huang R.L., Yin Y.L., Li T.J., Gao J.P.,Tao L.H., 2003. Techniques for implanting a chronic hepatic portal vein transonic flow meter and catheters in the hepatic portal vien, ileal mesenteric vein and carotied artery in swine. Zoonutr. Sinica. 15, Suppl. 1, 10-20

Kleesen B., Stoof G., Proll J., Schmiedl D., Noach J., Blaut M., 1997. Fceding resistant starch affects fecal and cecal microflora and short-chain fatty acids in rats. J. Anim. Sci. 75, 453-462

Nemcova R., Bomba A., Gancarikova S., Herich R., Guba P., 1999. Study of the effect of Lactobacillus paracasei and fructooligosaccharides on the faecal microflora in weanling pigs. Berl. Mun. Tierarztl. Wochenschr. 112, 225-228

Newman K.E., 1999. Mannan oligosaccharides - A review of scientific data on this novel ingredient. In: T.P. Lyons, D.J.A. Cole (Editors). Concepts in Pig Science Nutrtion. Nottingham (UK), pp. 47-52

Orban J.I., Patterson J.A., Adcola O., Sutton A.L., Richards G.N., 1997. Growth performance and intestinal microbial populations of growing pigs fed diets containing sucrose thermal oligosaccharides caramel. J. Anim. Sci. 75, 170-175

Patterson J.A., Burkholder K.M., 2003. Prebiotic feed additives: rationale and use in pigs. In: R.O. Ball (Editor). $9^{\text {th }}$ International Symposium on Digcstive Physiology in Pigs. Banff, Alberta (Canada), pp. 319-331

Pluske J.R., Siba P.M., David W.P., Zorica D., Mullan B.P., Hampson D.J., 1996. The incidence of swine dysentery in pigs can be reduced by feeding diets that limit the amount of fermentable substrate entering the large intestine. J. Nutr. 126, 2920-2933

Pluske J.R., Zorica D., David W.P., Mullan B.P., Hampson D.J., 1998. Confirmation of the role of rapidly fermentable carbohydrates in the expression of swine dysentery in pigs after experimental infection. J. Nutr. 128, 1737-1744

Rao D.S., McCracken K.J., 1991. Effects of energy intake on protein and energy metabolism of boars of high genetic potential for lean growth. Anim. Prod. 52, 499-507

Rerat A.A., Vaissade P., Vaugelade P., 1984. Absorption kinetics of some carbohydrates in conscious pigs. Brit. J. Nutr. 51, 505-529

Spring P., Privulescu M., 1998. Mannanoligosaccharide: its logical role as annatural feed additive for piglets. In: T.P. Lypons, K.A. Jacques (Editors). Biotechnology in the Feed Industry. Proceedings of Alltch's 14 ${ }^{\text {th }}$ Annual Symposium, Nottinghan University Press, pp. 553-561

Stockland W.L., 1999. Practical solution to maximise production: the commercial application of oligosaccharides in starter pig diets. In: T.P. Lyons, D.I.A. Cole (Editors). Concepts in Pig Science Nutrtion. Nottingham (UK), pp. 71-80

Topping D.L., Clifton P.M., 2001. Short-chain fatty acids and human colonic function: roles of resistant starch and nonstarch polysaccharides. Physiol. Rev. 81, 1031-1061

Topping D.L., Illman R.J., Clarke J.M., Jackson K.A., Marsono Y., 1993. Dietary fat and fibre alter large bowel and portal venous volatile fatty acids and plasma cholesterol but not biliary steroids in pigs. J. Nutr. 123,133-143

Yen J.T., Killefer J., 1987. A method for chronically quantifying net absorption of nutrients and gut metabolites into hepatic portal vein in conscious swine. J. Anim. Sci. 64, 923-934

Yin Y.-L., Baidoo S.K., Schulze H., Simmins P.H., 2001 a. Effect of supplementing diets containing hulless barley varieties having different levels of non-starch polsaccharides with $\beta$-glucanase and xylanase on the physiological status of gastrointestinal tract and nutrient digestibility of weaned pigs. Livest. Prod. Sci. 71, 97-107

Yin Y.-L., Baidoo S.K., Jin Z.L., Liu Y.G., Schulze H., Simmins P.H., 200lb. The effect of different carbohydrase and protease supplementation on apparent (ileal and overall) digestibility of nutrient of five hulless barley varieties in young pigs. Livest. Prod. Sci. 71, 109-120 
Yin Y.-L., Gurung Nar K., Jeaurond E.A., Sharpe P.H., de Lange C.F.M., 2002. Nutrient digestibility of Canadian-developed sorghum and pearl millet grains fed to growing pigs compared to traditional cereal grains. Can. J. Anim. Sci. 82, 385-391

Yin Y.-L., McEvoy J., Souffrant W.-B., Schulze H., McCracken K.J., 2000a. Apparent digestibility (ileal and overall) of nutrients and endogenous nitrogen losses in growing pigs fed wheat or wheat by-products without or with xylanase supplementation. Livest. Prod. Sci. 62, 119-132

Yin Y.-L., McEvoy J., Souffrant W.-B., Schulze H., McCracken K.J., 2000b. Apparent digestibility (ileal and overall) of nutrients as evaluated with PVTC-cannulated or ileo-rectal anastomised pigs fed diets containing two indigestible markers. Livest. Prod. Sci. 62, 133-141

Yin Y.-L., McEvoy J., Schulze H., McCracken K.J., 2000c. Studies on cannulation method and alternative indigestible markers and the effects of food enzyme supplementation in barley-based diets on ileal and overall apparent digestibility in growing pigs. Anim. Sci. 70, 63-72

Yin Y.-L., Zhong H.-Y., Huang R.-L., Chen C.-M., Li T.-J., Pai Y.-F., 1993. Nutritive value of feedstuffs and diets for pigs. I. Chemical composition, apparent ileal and fecal digestibility. Anim. Feed Sci. Tech. 44, 1-27

Zhou S.-M., 1999. Advance in oligosaccharide study and application. Feedstuff Res. 10, 14-16

Żebrowska T., 1973. Digestion and absorption of nitrogen compounds in the large intestine of pigs. Rocz. Nauk, rol. B-95, 65-70

\section{STRESZCZENIE}

\section{Żywieniowe i zdrowotne dzialanie węglowodanów u świń}

Największy postęp w badaniach nad węglowodanami w żywieniu świń oraz ich znaczenie dla zdrowia polega na tym, że są one bardzicj wyraźnie klasyfikowane nie na podstawie ich struktury, lecz także oddziaływania żywieniowego.

Węglowodany stanowią składnik struktur komórki, są źródłem energii oraz spełniają funkcje regulujące. Wystçpują duże różnice $w$ trawieniu, wchłanianiu oraz tempie pojawiania siç węglowodanów w osoczu krwi żyły wrotnej. Wielocukry nieskrobiowe (NSP), a zwłaszcza rozpuszczalne i oporne skrobie (RS), mają ujemny wpływ na wykorzystanie składników pokarmowych przez rosnące świnie, jednakże niektóre z NSP i RS mają korzystny wpływ na zdrowie. 